\title{
THE TRANSLATION OF FOREIGN NOVELS INTO MALAY BY DEWAN BAHASA DAN PUSTAKA
}

(Penterjemahan Novel Bahasa Asing ke dalam Bahasa Melayu oleh Dewan Bahasa dan Pustaka)

Haslina Haroon

haslina@usm.my

Melati Abdul Majid

miss_melati02@yahoo.com

Malay Language, Translation and Interpreting Section, School of Humanities, Universiti Sains Malaysia, 11800 USM, Penang, Malaysia.

Tel.: +604-6532864

\begin{abstract}
Established in 1956 with the main purpose of developing the Malay language, Dewan Bahasa dan Pustaka (DBP) has also played a pivotal role in the translation of foreign works into Malay. Very little, however, has been studied in terms of its contribution to the development of translation activities in Malaysia. This paper aims to provide an overview of the translation of foreign novels into Malay by DBP from the time of its inception. A survey was carried out for this purpose. The results show that a total of 72 foreign novels have been translated into Malay and published by DBP. The study was also able to determine specific trends in the translation of foreign novels by DBP. Although limited in scope, this study is believed to be important as it is able to contribute to existing discourse on the history of translation in Malaysia.
\end{abstract}

Keywords: translation, Dewan Bahasa dan Pustaka, publishing, novels, translation history 


\section{Abstrak}

Dewan Bahasa dan Pustaka, yang ditubuhkan pada tahun 1956 dengan matlamat utama untuk membina dan mengembangkan bahasa Melayu, sebenarnya juga telah memainkan peranan penting dalam penterjemahan karya asing ke dalam bahasa Melayu. Walau bagaimanapun, tidak banyak kajian yang dijalankan yang meneliti sumbangan DBP kepada perkembangan aktiviti penterjemahan di Malaysia. Makalah ini bertujuan untuk memberi gambaran tentang penterjemahan novel asing ke dalam bahasa Melayu oleh DBP sejak penubuhannya. Untuk mencapai tujuan ini, satu tinjauan dilakukan. Dapatan menunjukkan bahawa sejumlah 72 buah novel asing telah diterjemahkan dan diterbitkan oleh DBP. Kajian ini juga mengenal pasti beberapa kecenderungan dalam penterjemahan novel asing oleh DBP. Walaupun skopnya agak kecil, kajian ini dirasakan penting kerana ia dapat menyumbang kepada wacana sedia ada tentang sejarah penterjemahan di Malaysia.

Kata kunci: terjemahan, Dewan Bahasa dan Pustaka, penerbitan, novel, sejarah penterjemahan

\section{INTRODUCTION}

Research and writings that focus on the tradition of translation in Asia are few and far between compared to those that focus on the tradition of translation in the West. In discussing the tradition of translation in Asian countries, Hung and Wakabayashi (2005:1) assert that their volume Asian Translation Traditions (2005) emerged from what is perceived as "the bias in the contemporary field of Translation Studies, which remains highly Eurocentric both in its theoretical explorations and its historical grounding". They further add that "the discipline of Translation Studies lacks reliable data and systematic analyses of translation activities in non-European cultures" (Hung and Wakabayashi, 2005:1). Similarly, Ricci and van der Putten (2011:1), in their own volume Translation in Asia: Theories, Practices, Histories, remark that "the histories of translation into, and from, many Asian languages, although long and complex, to a large extent remain obscure or, at best, fragmentary". This article is an attempt at documenting one aspect of the history of translation involving the Malay language in Malaysia. More specifically, this article attempts to examine the translation of foreign novels into Malay by Dewan Bahasa dan Pustaka (DBP) (the language and literary development agency of Malaysia) since its inception. By focusing on one aspect of the history of translation in Malaysia, this article hopes to 
not only contribute to the existing discourse on the history of translation in the context of Malaysia but also to add to the documentation of translation activities involving a non-European culture.

\section{TRANSLATION STUDIES AND THE HISTORY OF TRANSLATION}

According to Hatim and Munday (2004), the development of translation studies over the years means that it now also incorporates other fields of study such as philosophy, language engineering, cultural studies, literary studies and also history. Many other scholars have also remarked on the inclusion and development of the field of history as a legitimate area of research in the field of translation studies. Williams and Chesterman (2002), for example, include history as one of the main research areas in the field of translation, together with other areas such as text analysis and translation, translation quality assessment, genre translation, multimedia translation, translation and technology, ethics in translation, terminology and glossary, interpretation, and the process of translation. They further explain that "the major research questions in translation history are to do with: Who? What? Why? And How?" (Williams and Chesterman, 2002:16). It is stressed that it is an area of research which looks into "which texts are translated (or not translated) in particular cultures at particular times" (Williams and Chesterman, 2002:17).

Research of this nature was also mentioned by Holmes as early as 1988 . According to Holmes, a study such as this falls under the ambit of functionoriented descriptive translation studies, the focus of which is the following :

... it is a study of contexts rather than texts. Pursuing such questions as which texts were (and, often as important, were not) translated at a certain time in a certain place, and what influences were exerted in consequence, this area of research is one that has attracted less concentrated attention [...], though it is often introduced as a kind of a sub-theme or counter-theme in histories of translations and in literary histories. Greater emphasis on it could lead to the development of a field of translation sociology (or-less felicitous but more accurate, since it is a legitimate area of translation studies as well as of sociology-socio-translation studies.

(Holmes, 1988/2004:185)

This makes it clear that the main focus in research of this nature is an examination of the types of texts chosen to be translated at a particular time by a particular organization. A similar proposal was put forth by Šajkevič 
(1992:67) who suggests that research which looks into the process of translation should focus not only on linguistic aspects but also on the sociological aspects of translating. In other words, research in the field of translation should be concerned not only with the question of how texts are translated but also with the question of what texts are chosen to be translated.

\section{THE TRANSLATION ACTIVITIES OF DEWAN BAHASA DAN PUSTAKA (DBP)}

In Malaysia, one of the organizations involved in translation activities in Malaysia is Dewan Bahasa dan Pustaka (DBP), which is Malaysia's national Language and Literary Development Agency. According to the organization's annual report, DBP was established in Johor Bahru, Johor, Malaysia on 22 June 1956 under the name Balai Pustaka, with the aim of developing the Malay language which was to be the official language of the country upon its independence (Laporan Tahunan Dewan Bahasa dan Pustaka, 2008: 4). DBP moved to Kuala Lumpur in 1957 and today remains one of the main reference centres in Malaysia for matters relating specifically to language and literature.

The annual report also states that the specific objectives behind the establishment of the organization is to develop and enrich the national language in every field including science and technology, to publish or assist in the publication of books and magazines in the national language, to standardize the spelling and pronunciation of words in the national language, to create new terminology in the national language, and to encourage the correct and widespread use of the national language. None of the objectives mention translation as one of the activities of DBP. It can, nevertheless, be assumed that the publication of books also includes the publication of translations. The fact that DBP was engaged in translation activities, specifically in the translation of foreign literary works, can be seen in the numerous translations that it has published. This effort began in 1958 with the publication of the first translated novel by DBP entitled Anak Raja dengan Anak Papa, the translation of Mark Twain's The Prince and the Pauper by the Malay translator, Zainal Abidin bin Ahmad.

In Dewan Bahasa dan Pustaka Sa-Puloh Tahun, a report published in 1967 which documented the activities of the organization in the first ten years of its establishment, it was mentioned that up until 1966, DBP had already published a total of 141 translations. From this number, a total of 105 titles were translated by the Translation Department of DBP while 36 
titles were translated by external translators appointed by DBP. In addition to that, 93 translations were also in process (Dewan Bahasa dan Pustaka Sa-Puloh Tahun, 1967:28).

According to Foong (1989), translation activities at DBP were originally under the purview of the Translation Department. This department was, however, dissolved in 1970 because of a lack of expertise in translation. A Translation Unit was, however, set up in the mid-1970s, under Bahagian Pembinaan dan Pengembangan Sastera (Literature Building and Development Division). Due to internal restructuring, the unit was also later dissolved but a new Translation Section was established in 1986.

In 1995, all translation activities managed by DBP were taken over by Institut Terjemahan Negara Malaysia (ITNM) or the Malaysian National Institute of Translation. With the establishment of the translation institute, it seemed appropriate, too, to close down the Translation Section at DBP, a move which was also in line with the restructuring of the organization at that time. With the closing down of the Translation Section, all translation work and other activities related to the publication of translated works began to be undertaken by ITNM. Today, the translation institute, now known as Institut Terjemahan \& Buku Malaysia (ITBM) or the Malaysian Institute of Translation and Books, is the leading translation organization in the country. DBP, meanwhile, has ceased to be actively involved in activities relating to translation. The fact remains, however, that DBP has played an instrumental role in producing and publishing translated works for close to 40 years in Malaysia.

In spite of that, documentation relating to translated works is lacking. Documentation such as this is seen as important as it may be a source of reference to identify, for example, which titles have been translated or the translators involved in the translation process. It is this perceived gap in the information available on the involvement of DBP in translation activities in Malaysia that has led to this study, which aims to provide an overview of the translation into Malay of a specific literary form, the novel, by DBP since its inception in 1956.

\section{THE DOCUMENTATION OF TRANSLATED WORKS}

Although the field of translation studies is traditionally concerned with the question of how works are translated, often focusing on strategies and procedures adopted by translators in the process of translation, it has over 
the years begun to look into the question of what materials are translated. This quite necessarily involves the activity of documenting translated works or producing a bibliography of translations.

The documentation of translated works is carried out to look at not only what is being translated but also the characteristics of the works which are translated. This can be seen, for example, in the study by Yoong and Zainab (2002) which, in the first stage, involved compiling a list of classical Chinese literary works translated into Baba Malay from 1889 to 1950. The second stage of the study is a bibliometric analysis of the works in the list in order to uncover specific details relating to the publication. In this study, Yoong and Zainab (2002) examined the titles in order to find information regarding the people involved (translators, editors, illustrators, readers and assistants), the publishers and printers, the subject content of the translated works, the physical condition of the translations, as well as the location of each title.

An almost similar approach was also adopted by Linn (2006) in examining translation trends from Dutch into Spanish from 1950 to 2000. Before the analysis could be carried out, a list of titles translated from Dutch during this period in all fields of study was compiled. This was achieved by consulting numerous bibliographies which list translations carried out from Dutch. Linn's (2006) objective was to examine trends in terms of the fields translated; the list obtained, therefore, was analysed according to certain predetermined fields, for example, religion, philosophy, social science, literature, children's literature, art, etc. Linn (2006) then identifies the number of publications in each field every five years over a period of 50 years. It must be noted that Linn (2006) not only examines trends in translating but also attempts to explain social and ideological factors which may have contributed to the trends.

Another study which is of relevance to this particular study was carried out by Raja Masittah (2008). The study focuses on describing translations carried out from foreign languages into Malay and published in Malaysia (including Singapore). In the first stage of the study, research was carried out to determine which foreign works have been translated into Malay. The result is a list of 1382 translated titles in Malay in various fields from the time of pre-Independence Malaysia until 2008. The second stage of the study involved analysing the list in order to determine the fields translated as well as publishers involved in translation. This present study is in many ways similar to the study carried out by Raja Masittah but it also differs from this in that it focuses on translations published only by DBP. The present study also narrows its scope by focusing only on translated novels. 
Another significant study is that carried out by Gerber (2008), which focuses on the translation of Australian children's fiction into German from 1854 to 2007 . While most of the studies previously mentioned focus on the compilation of lists in order to uncover trends in the publication of translated titles, Gerber's (2008) focus is on the actual process of compiling a bibliography of translated titles. The nature of this study means that Gerber's study is an invaluable source in terms of the approach that needs to be taken and the difficulties faced in the process. Gerber (2008:143), for example, suggests a three-fold research strategy that involves examining established bibliographies, consulting online library catalogues and visiting libraries in the process of compiling the bibliography required. This process is not without difficulties. As explained by Gerber, there are likely to be problems even when the most comprehensive bibliography is available:

...it sometimes lacks information, such as the translator's name and/or the date of publication; it occasionally was recorded incorrectly - this was discovered later when cross-checking; and edition numbers were sometimes confusing. Such inaccuracies are most likely not the fault of the editors, but a result of the haphazard way in which such information is often recorded.

(Gerber, 2008:144)

Gerber (2008) elaborates in detail some of the other obstacles faced in obtaining the required bibliographic information:

Across all sources, the translator's name was recorded in a rather ad hoc manner; sometimes it was provided, other times not. Even more frustratingly, when omitted in one source, it was usually missing in others. Another common problem (which is slowly improving) was the provision of the title of the translation, but not the original source text title; this meant "working backwards" and deciphering the original title by back-translating or matching dates with the author's works.

(Gerber, 2008:144)

It might be assumed that the problem of obtaining the correct bibliographic details may be resolved by accessing the actual text in person, but this is not always the case: "the precise details of all texts were not always at hand. The inside covers of some of the older translations - particularly those from the $1950 \mathrm{~s}$ - contained no information about either the source text title or name of translator" (Gerber, 2008:144). In spite of the numerous obstacles 
faces in compiling the required information, the bibliography which resulted from the process was able to reveal the number of translated titles and also preferences and trends where authors and themes are concerned.

In some cases, the task of trying to uncover what is translated involves a list that is readily available. The researcher, therefore, does not have to engage in the laborious task of identifying translated titles. Šajkevič (1992), for example, made use of a readily available database, the Index Translationum, which is an international annual bibliography featuring translations published by UNESCO member states. The focus of the study was to identify trends in the translated works published. According to Šajkevič (1992:67), despite the fact that the bibliography is a huge source of information on translation, it has never been subjected to a comprehensive analysis. Šajkevič (1992:67), however, acknowledges the fact that such a large database presents the usual problems of irregularities and omissions. In spite of this, the survey carried out was able to uncover data on the number of translations published as well as data relating to the source language of translations, fields translated and the original writers chosen for translation.

All these previous studies point to the documentation of translated works as a valid area of research in the larger field of translation studies. Perhaps more importantly, these studies are able to provide useful guidelines as to how a similar study can be conducted in the context of Malaysia.

\section{METHOD}

The aim of this paper is to provide an overview of the translation into Malay of a specific literary form, the novel, by DBP since its inception in 1956. In order to obtain the complete documentation of foreign novels translated into Malay by DBP, the first step involves compiling a list of translated titles. In doing so, this study adopts the three-fold approach suggested by Gerber (2008), that is, by first examining established bibliographies, followed by consulting online library catalogues and finally visiting libraries. The need for a previously established bibliography in order to kick-start the search is also mentioned by Pym (1998). He stresses that one of the main challenges in producing a list of translated works is that "they inevitably depend on previous lists of one kind or another, usually catalogues compiled by publishers or libraries..." (Pym, 1998:41). Thus, in order to produce a complete list of foreign novels which have been translated by DBP into Malay from 1956, the following sources were consulted and referred to: 
a) Karya Sastera dalam Terjemahan: Satu Bibliografi, published by DBP in 1978.

b) Katalog Judul Terjemahan, published by DBP in 1991 .

c) Karya Sastera dalam Terjemahan: Bibliografi Terpilih, published by DBP in 1993.

d) Novel-Novel Terjemahan Terbitan DBP: Satu Tinjauan, an academic exercise carried out in 1989 by Foong Yin Kheng.

e) "Kepustakaan Terjemahan dalam Bahasa Melayu", a 2008 research paper by Raja Masittah Raja Ariffin.

While the sources are undoubtedly useful in identifying titles of translated novels published by DBP and in gathering other relevant information, none of these sources have a complete and definitive list of all the titles of foreign novels translated into Malay by DBP from 1956 onward. The academic exercise by Foong (1989), for instance, only lists translations of novels from 1956 to 1987. As seen previously, both Šajkevič (1992) and Gerber (2008) mention the problem of irregularities and omissions when dealing with a database of publications. This issue of incompleteness is also raised by Poupaud, Pym and Torres Simón (2009) in their effort to identify relevant information relating to translation in the Index Translationum, for example, information about translations according to genre, the translators and publishers involved and year of publication. Therefore, in order to ensure that data obtained for this study is complete, this study also referred to the following online catalogues:

a) Online Public Access Catalogue, Hamzah Sendut Library, Universiti Sains Malaysia,

b) Online Public Access Catalogue, the National Library of Malaysia.

Besides striving for completeness, the study also tries to ensure the accuracy of the data collected. Taking into account the issue of inaccuracy in the recording of bibliographic details as pointed out by Gerber (2008), each of the translated titles in the list was physically examined during visits to both the National Library, Kuala Lumpur and the Hamzah Sendut Library, Universiti Sains Malaysia, Penang. This is to ensure that the titles and other details such as names of translators and year of publication are accurate. 


\section{RESULTS}

\section{Number of Translated Novels Published}

The survey that was carried out reveals that a total of 72 novels were translated from foreign languages into Malay and published by DBP since the time of its establishment. The first translated novel was published in 1958 while the final one was published in 2001. The details pertaining to these translated novels were then recorded in the form of a list, thus enabling the researcher to analyse it in order to determine specific trends and preferences in the translation of foreign novels into Malay.

\section{List of Translated Novels}

In order to determine trends and preferences in the translation of foreign novels into Malay by DBP from 1958 to 2001, documentation takes into account the following details:

a) The title of the translation in Malay.

b) The title of the original novel.

c) The name of the original author.

d) The language of the original novel.

e) The title and language of the source text, that is, the text on which the translation is based (if different from [b] and [d]).

f) The name of the translator.

g) The year of publication of the translation.

The details for each translated title is shown in Appendix (pp. 147-56). The translated titles are listed in chronological order, starting from the first foreign novel translated into Malay by DBP in 1958.

The first column in Appendix shows the number of novels published by DBP. The second column provides the title of the translated novel in Malay as published by DBP. In the third column, information about the title of the original novel, the name of the original writer and the original language of the novel is provided. The fourth column, meanwhile, gives information about the novel from which the translated text is produced. For example, the penultimate translated novel published by DBP is Haji Murat. The fourth column for this title gives information about the text on which the translation is based. In this particular case, the text is Hadji Murat in Russian. This information is the same as that in the third column; this, therefore, indicates that the translated novel entitled Haji Murat is translated directly from its Russian original entitled Hadji Murat. 
As a point of comparison, the last translated title published by DBP is Riwayat Mayta. The fourth column for this title provides information on the novel from which the translation is carried out, which is a novel in English entitled The Real Life of Alejandro Mayta. This is not the same as the information given in the third column, where we are shown the title of the original novel, Historia de Mayta, the name of the original writer, Mario Vargas Llosa, and the language of the original novel, Spanish. This indicates that the translated novel in Malay entitled Riwayat Mayta is not translated directly from the original Spanish novel, Historia de Mayta, but is translated from an intermediary text entitled The Real Life of Alejandro Mayta. This information is easily obtained by examining the edition notice or copyright page of the translated novel in Malay (see Fig. 1). This information on the intermediary text which is included in the fourth column would enable us to compare the number of translated novels which are translated directly from the original language and the number of translated novels which are translated using intermediary texts. The fifth column lists the name of the translator(s) while the sixth column provides the year of publication of each translated novel.

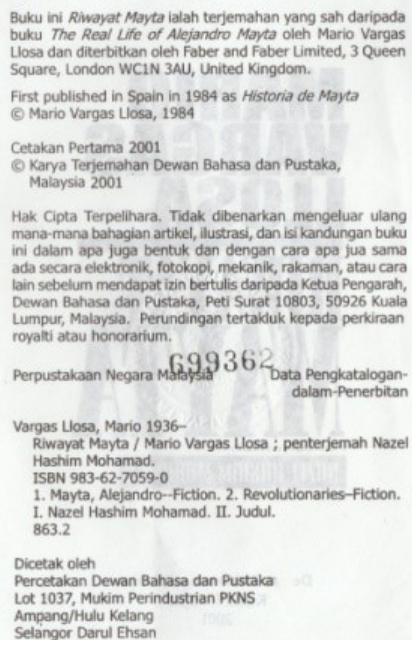

Figure 1 The edition notice or copyright page of Riwayat Mayta (2001), which provides information about the original novel in Spanish, Historia de Mayta, and the source text in English, The Real Life of Alejandro Mayta, upon which the Malay translation is carried out. 


\section{Languages Involved in Translation}

This study makes a distinction between "original language" and "source language". As mentioned previously, the term "original language" is used to refer to the language in which the novel was originally written. The "source language", meanwhile, is the language based on which the translation was carried out. The "original language" and the "source language" is therefore the same if the translator is able to work from the "original language". The "source language", however, is different from the "original language" if the translation into Malay, the target language, involves an intermediary text, i.e. a translation in another language. The languages involved in the translation of novels by DBP are shown in Table 1 .

It can be seen from Table 1 that twelve different languages are represented in the translation of foreign novels into Malay by DBP. English tops the list, with almost half of the total number of translations undertaken from this language. Works in English which are chosen for translation into Malay are

Table 1 The translation of novels into Malay and the languages involved.

\begin{tabular}{|c|c|c|c|}
\hline $\begin{array}{c}\text { Original } \\
\text { Translation }\end{array}$ & $\begin{array}{c}\text { Number of } \\
\text { Translations }\end{array}$ & $\begin{array}{c}\text { Number of } \\
\text { Translations } \\
\text { Carried } \\
\text { Out from } \\
\text { the Original } \\
\text { Language }\end{array}$ & $\begin{array}{c}\text { Number of } \\
\text { Translations } \\
\text { Carried Out } \\
\text { Based on an } \\
\text { Intermediary }\end{array}$ \\
\hline English & 35 & 35 & - \\
\hline Japanese & 12 & 3 & 9 \\
\hline French & 6 & 5 & 1 \\
\hline Arabic & 4 & 1 & 3 \\
\hline Russian & 4 & 1 & 2 \\
\hline Chinese & 3 & 2 & 1 \\
\hline Spanish & 2 & - & 1 \\
\hline Thai & 2 & 1 & 1 \\
\hline Burmese & 1 & - & - \\
\hline Italian & 1 & - & 23 \\
\hline German & 1 & - & 1 \\
\hline Tamil & 1 & 49 & \\
\hline & 72 & & 1 \\
\hline
\end{tabular}


not only novels by American and British writers but also, among others, novels by writers from Africa, India and the Philippines originally written in English. Translations from Japanese account for approximately 17 per cent of the total number of translations published by DBP, while eight per cent of the translations are from French. The other nine languages represented in translation into Malay all have less than five translations each.

Out of the 72 translations, almost 70 per cent (49 titles) are direct translations, i.e. translations which are carried out directly from the original language without the assistance of intermediary texts. Most of the translations are from English. The single Tamil novel was also translated directly from the original language. The translations involving Spanish, Burmese, Italian and German, meanwhile, were done exclusively with the help of intermediary texts in English. The use of the intermediary texts in translation involving these languages seems to point to the lack of translators who are proficient in those languages. With all the other works, some were translated directly from the original text while others were produced using intermediary translations.

\section{Translations by Year}

The survey reveals that the first translated novel was published in 1958 while the final one was published in 2001. This indicates that several titles continued to be published by DBP after 1995, that is, after the Department

Table 2 The number of translated novels published by year.

\begin{tabular}{|c|c|}
\hline Year & $\begin{array}{c}\text { Number of } \\
\text { Translations }\end{array}$ \\
\hline $1958-1959$ & 1 \\
\hline $1960-1964$ & - \\
\hline $1965-1969$ & 1 \\
\hline $1970-1974$ & - \\
\hline $1975-1979$ & 4 \\
\hline $1980-1984$ & 3 \\
\hline $1985-1989$ & 14 \\
\hline $1990-1994$ & 32 \\
\hline $1995-1999$ & 13 \\
\hline$>2000$ & 5 \\
\hline & 72 \\
\hline
\end{tabular}


of Translation at DBP had ceased operation. Table 2 shows the number of foreign novels translated into Malay by year.

It can be seen that the publication of translated novels was rather slow in the first two decades after the establishment of DBP. It was only in the second half of the 1970s that the publication of translated novels began to pick up. This is probably due to the effort by the Translation Unit at DBP, which was set up in the mid-1970s. The number of translations published continued to increase in the 1980s, with the second half showing a vast increase in the number of translations published compared to the first half of the 1980s. This very encouraging trend continued in the 1990s. It must be noted, however, that there is a sharp decrease in the number of translated novels published in the second half of the 1990s compared to the number published in the first half of the 1990s. The publication of translated novels by DBP came to an end in 2001 , with only two translations published in the final year.

\section{Translators Involved}

Based on the information compiled, the translation of foreign novels into Malay by DBP from 1958 to 2001 involved a total of 51 translators. Out of the 72 translated titles, 57 titles or 79.2 per cent were produced by single translators while 15 titles or 20.8 per cent were produced by groups of translators (13 titles) or though a translation service (two titles). The most prolific translator is Shamsuddin Jaafar, with seven translations to his name. Both Mokhtar Ahmad and Zulkifli Ahmad are also productive translators, with six translations each. It is also interesting to note that for almost all the translated novels published by DBP, the translator's name appears on the front cover and on the title page, thereby ensuring that the translators are given recognition for their effort in making available those foreign novels in the form of translation in Malay.

\section{Choice of Novels for Translation}

In terms of the novels chosen for translation, it can be said that many are highly acclaimed novels which have been awarded some form of recognition. Many of the novels translated from Japanese, for example, have won national awards. Jiro Osaragi's Kikyo won the Japan Art Academy Prize in 1950 while Yukio Mishima's Shiosai won the Shinchosa Literary Award in 1954. The novel Onnazaka by Fumiko Enchi won the Noma Literary Prize in 1957, while Kuroi Ame by Masuji Ibuse won the same award in 1966. Harper Lee's To Kill a Mockingbird, meanwhile, was awarded the Pulitzer 
Prize in 1961. In Thailand, Kham Phi Phaksa by Chart Kobjitti won the 1982 Book of the Year Award which was given by the Literary Council of Thailand. Meanwhile, Tahar ben Jelloun's La nuit Sacrée was awarded the most prestigious prize in French literature, the Prix Goncourt in 1987.

Many of the novels chosen for translation are also written by authors who have been given some form of recognition in the form of international, regional or national awards. For instance, both Chart Kobjitti and Nikhom Raiyawa, the original writers of Korban Fitnah (1988) and Tebing Tinggi (1991), respectively, were recipients of the S.E.A Write Award, an award given annually to writers from Southeast Asia. Chart Kobjitti was the recipient of the award in 1982 while Nikhom Raiyawa received the same award in 1988. Some of the writers chosen were also notable winners of the Nobel Prize in Literature, for example, William Faulkner (1949), Ernest Hemingway (1954), Albert Camus (1957), Yasunari Kawabata (1968), Patrick White (1973), Gabriel García Marquez (1982), Wole Soyinka (1986), and Naguib Mahfouz (1988).

While it cannot be ascertained whether the awards bestowed upon the writers or won by the original novels were part of the criteria for choosing the work to be translated, it is clear that in some instances DBP made use of the awards received as a selling point and to promote the translation. For example, the front cover of the novel Korban Fitnah (1998) which is a translation of Chart Kobjitti's Kham Phi Phaksa (though an intermediary translation entitled The Judgment) features Chart Kobjitti's name and one of his many accolades beneath it in parentheses, i.e. "Pemenang Hadiah S.E.A 1982" (Winner of the 1982 S.E.A. Write Award) (see Fig. 2). Similarly, the front cover of the Malay translation of Patrick White's Voss informs the readers that the writer is "Pemenang Hadiah Nobel bagi Kesusasteraan 1973" (Winner of the 1973 Nobel Prize for Literature). A similar feature can be seen on the front cover of the novel Lorong Midaq (1983), the translation of Naguib Mahfouz's Zuqaq al-Midaq (through an English intermediary text Midaq Alley). Placed at the top right corner of the front cover is crucial information about the author for the readers, i.e. that the author is "Pemenang Hadiah Nobel untuk Kesusasteraan 1988" (Winner of the 1988 Nobel Prize for Literature). Still another example can be seen by examining the back cover of Hujan Hitam (1993). The back cover of the Malay translation of Masuji Ibuse's Kuroi Ame (through an intermediary translation entitled Black Rain) mentions that the book "dianugerahkan Hadiah Noma" (was awarded the Noma Prize) (see Fig. 3). 


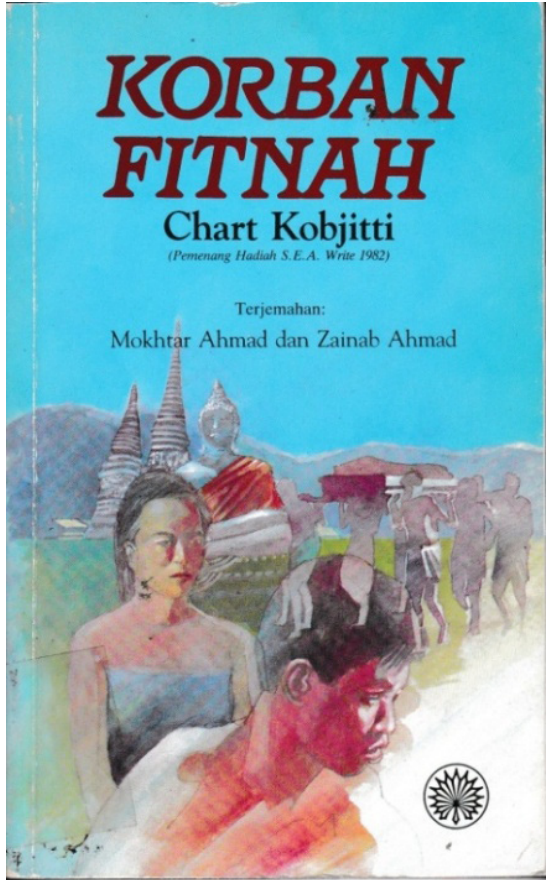

Figure 2 The front cover of Korban Fitnah (1988), the Malay translation of the Thai novel Kham Phi Phaksa, which highlights one of the accomplishments of the original author, Chart Kobjitti.

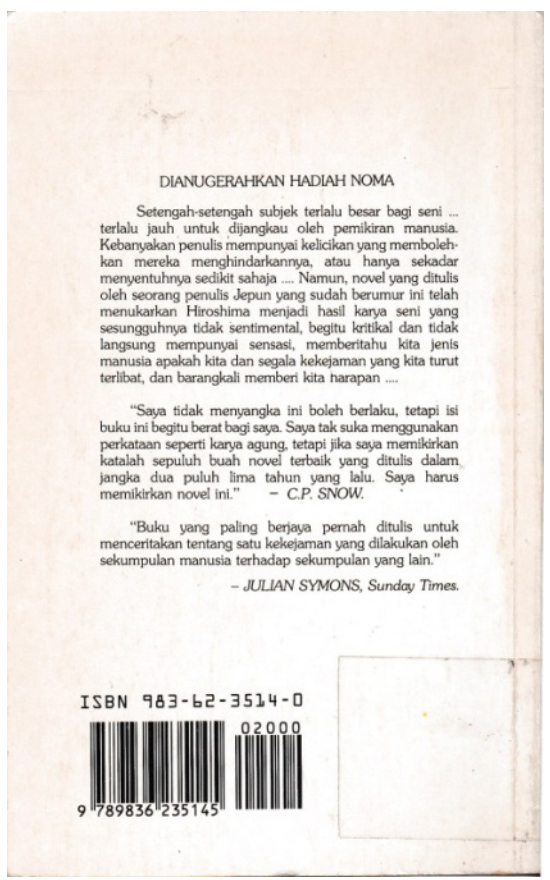

Figure 3 The back cover of Hujan Hitam (1993), where mention is made of one of the awards received by the original Japanese novel, Kuroi Ame.

\section{Assistance and Funding in the Publication of Translations}

An analysis of the translated texts also reveals that the publication of some of the translations was made possible through assistance from certain organizations. This information is gathered by examining the edition notice and the acknowledgement page in the translation.

Some of the translations from the Japanese, for instance, Hujan Hitam (1993), Ibu oh Ibu! (1994) and Tahun-tahun yang Dinanti (1995) were published in arrangement with Kodansha International Ltd., a prominent publishing company in Japan. The publication of these translations was also 


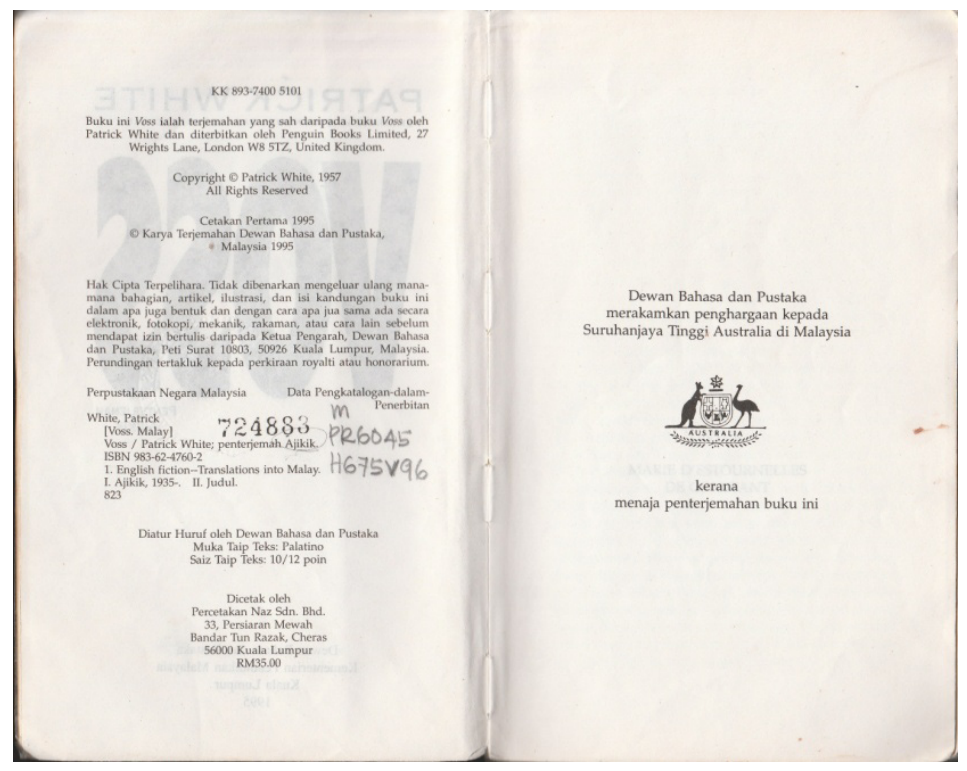

Figure 4 Acknowledgement by DBP of the assistance provided by the Australian High Commission in funding the translation of Voss (1995).

made possible through funding granted by Toshiba International Foundation in Japan. The availability of funding also made possible the translation into Malay of America's epic novel, Moby Dick. In this particular case, funding was provided by the United States Information Service (USIS). Meanwhile, in the Malay translation of Voss (1995), a novel by the Australian author Patrick White, DBP clearly acknowledges assistance provided by the Australian High Commission in funding the translation of the book (see Fig. 4).

\section{Paratextual Information}

Paratext is defined as "those liminal devices and conventions, both within the book (peritext) and outside it (epitext), that mediate the book to the reader: titles and subtitles, pseudonyms, forewords, dedications, prefaces, intertitles, notes, epilogues and afterwords" (Genette, 1997:xviii). In terms of physical appearance, almost all the front covers of the translations feature the name(s) of the translator(s), together with the title of the translation in Malay and the name of the original author. On the copyright page, one can find the publication information and details regarding the use of an intermediary text, if the translation involves such a text. 
Most of the translated novels are not accompanied by paratextual elements such as forewords, prefaces, notes and glossaries. In cases where these paratextual elements are found, they provide useful information for the readers. The novel Haji Murat (2001), for instance, contains a foreword written by the Malaysian novelist, Anwar Ridhwan. In the foreword, mention is made of the fact that the translator, Victor Pogadaev, having been educated at University Malaya in the early 1970s, is fluent in the Malay language and carried out the translation directly from the original Russian. As a result of translating directly from the original language, the translator, according to Anwar Ridhwan, has managed to produce a more faithful and accurate translation. Ainon Abu Bakar, the translator of Desa Salji (1993), also provides useful information in the translator's preface. Ainon, for example, talks about her choice of title for the Malay translation, important themes in the novel, the style of writing of the original author, and also strategies adopted in the translation of the novel, thus providing the readers with useful information before they begin reading the translation.

In terms of how the translations are presented to readers, it is noted that some of the translations provide explanatory details in the form of footnotes, although this does not appear to be a widespread practice by DBP. This can be seen, for example, in the novel Haji Murat (1993) (see Fig. 5), where the translator retained the use of certain foreign words in the Malay translation and inserted footnotes with explanatory details at the bottom of the page. Similarly, the use of glossaries is also rare. A rather lengthy glossary, however, can be seen in the novel Anak Raja dengan Anak Papa (1958) (see Fig. 6). This is due to the fact that the translator made use of numerous Malay words which readers may not be familiar with. The glossary, thus, serves as a useful reference to assist readers in understanding the meanings of words used.

\section{CONCLUSION}

This paper has attempted to provide an overview of the translation of foreign novels into Malay by DBP from the time of its establishment. The study has been able to identify 72 translated novels which were published in Malay by DBP, with the first translated novel published in 1958 and the final novel in 2001.

While it is limited in scope, this paper is believed to be important as there exists no complete documentation of the translation activities of DBP, despite the fact that the organization was instrumental in translation 
Figure 5 The use of footnotes in the

\section{I}

DRISTIWA ini terjadi pada penghujung tahun 1851.

Pada suatu malam bulan November yang sejuk, Haji Murat masuk menunggang kuda ke $a u l^{\prime}$ Chechen ketika asap kizyak ${ }^{2}$ yang berbau berkepul-kepul. Muazin baru selesai melaungkan azan yang nyaring. Di udara bersih daerah pergunungan yang diresapi bau asap kizyak itu azan tadi jelas kedengaran, selain bunyi air terjun, suara parau lelaki dan perempuan yang bertingkah, dan suara kanak-kanak dengan dilatari bunyi lembu menguak dan bunyi kambing biri-biri mengembek yang ditempatkan di saklya-saklya ${ }^{3}$ yang berangkai padat satu sama lain seperti sarang lebah.

I Petempatan di Kaukasia.

Najis binatangyang dipampat dan digunakan sebagai bahan Najis binatang yang dipampat das
bakar di daerah Selatan Rusia.

3 Perkataan Rusia untuk rumah penghuni gunung Kaukasia.

\section{menyembar menyambat

420

\section{novel Haji Murat (1993).}


activities in Malaysia for almost four decades. More importantly, this paper provides a list of translated novels and reveals certain trends and preferences related to their publication. Gerber (1998:154) notes that while documenting bibliographic information relating to translations and identifying certain trends in the publication may be important, there is also the need to gain a better understanding of the individual translation process and to examine the translations of particular translators or perhaps particular authors. The list compiled can therefore be a useful initial guide for this purpose. Additionally, this study would also be useful as a point of comparison with future research involving the translation of other literary genres such as dramas and short stories by DBP or research involving translations published by other publishing houses or organizations. Studies of this nature would be able to contribute to a more complete picture of translation activities and translation history in Malaysia.

\section{REFERENCES}

Dewan Bahasa dan Pustaka Sa-Puloh Tahun, 1967. Kuala Lumpur: Dewan Bahasa dan Pustaka.

Foong Yin Kheng, 1989. "Novel-Novel Terjemahan Terbitan Dewan Bahasa dan Pustaka: Satu Tinjauan". Latihan ilmiah Sarjana Muda Sastera, Jabatan Persuratan Melayu, Fakulti Sains Kemasyarakatan dan Kemanusiaan, Universiti Kebangsaan Malaysia. [Academic Exercise for Bachelor of Arts in Literature, Malay Studies Department, Faculty of Social Sciences and Humanities, Universiti Kebangsaan Malaysia]

Genette, G., 1997. Paratexts: Thresholds of Interpretation. Cambridge: Cambridge University Press.

Gerber, L., 2008. "Building Bridges, Building a Bibliography of Australian Children's Fiction in German Translation 1854-2007" in New Review of Children's Literature and Librarianship 14:2, pp. 141-57, 2008.

Hatim, B. and Munday, J., 2004. Translation: An Advanced Resource Book. London and New York: Routledge.

Holmes, J.S., 1988/2004. "The Name and Nature of Translation Studies" in Translated! Papers on Literary Translation and Translation Studies. Amsterdam: Rodopi: 67-80; reprinted in L. Venuti, (ed.). The Translation Studies Reader. 2nd edn. London and New York: Routledge.

Hung, E. and Wakabayashi, J. (eds.), 2005. Asian Translation Traditions. Manchester: St. Jerome.

Karya Sastera dalam Terjemahan: Bibliografi Terpilih, 1993. Kuala Lumpur: 
Dewan Bahasa dan Pustaka.

Karya Sastera dalam Terjemahan: Satu Bibliografi, 1978. Kuala Lumpur: Dewan Bahasa dan Pustaka.

Katalog Judul Terjemahan, 1991. Kuala Lumpur: Dewan Bahasa dan Pustaka.

Laporan Tahunan Dewan Bahasa dan Pustaka, 2008. Kuala Lumpur: Dewan Bahasa dan Pustaka.

Linn, S., 2006. "Trends in the Translation of a Minority Language: The Case of Dutch" in Pym, A. Shlesinger, M. and Jettmarová, Z., (eds.), Sociocultural Aspects of Translating and Interpreting. Amsterdam dan Philadelphia: John Benjamins, pp. 5-30.

Online Public Access Catalogue, Hamzah Sendut Library, Universiti Sains Malaysia at http://lib.usm.my (Accessed 15 April 2014]).

Online Public Access Catalogue, the National Library of Malaysia at http:// webopac.pnm.gov.my (Accessed 24 April 2014).

Poupaud, S., Pym, A. and Torres Simón, E. 2009. "Finding translations: On the Use of Bibliographical Database in Translation History" in Meta 54:2, pp. 264-78, 2009.

Pym, A. 1998. Method in Translation History. Manchester: St. Jerome.

Raja Masittah Raja Ariffin, 2008. "Kepustakaan Terjemahan dalam Bahasa Melayu" in Abdullah Hassan et al. (eds.), Membina Kepustakaan dalam Bahasa Melayu. Kuala Lumpur: ITNMB and PTS.

Ricci, R. and van der Putten, J. (ed.), 2011. Translation in Asia: Theories, Practices, Histories. Manchester: St. Jerome.

Šajkevič, A.J., "Bibliometric analysis of Index Translationum” in Meta 37:1, pp. 67-96, 1992.

Williams, J. and Chesterman, A., 2002. The Map: A Beginner's Guide to Doing Research in Translation Studies. Manchester: St. Jerome.

Yoong, S.K and Zainab, A.N., "Chinese Literary Works Translated into Baba Malay: A Bibliometric Study" in Malaysia Journal of Library \& Information Science 7:2, pp. 1-23, 2002. 
APPENDIX

\section{The Translated Titles in Chronological Order}

\begin{tabular}{|c|c|c|c|c|c|}
\hline No. & $\begin{array}{c}\text { Title of } \\
\text { Translation } \\
\text { in Malay }\end{array}$ & $\begin{array}{c}\text { Title of } \\
\text { Original } \\
\text { Novel, Name } \\
\text { of Original } \\
\text { Author and } \\
\text { Original } \\
\text { Language of } \\
\text { Novel }\end{array}$ & $\begin{array}{c}\text { Title of } \\
\text { Source Text }\end{array}$ & $\begin{array}{l}\text { Name of } \\
\text { Translator }\end{array}$ & $\begin{array}{c}\text { Year of } \\
\text { Publication }\end{array}$ \\
\hline 1. & $\begin{array}{l}\text { Anak Raja } \\
\text { dengan } \\
\text { Anak Papa }\end{array}$ & $\begin{array}{l}\text { The Prince and } \\
\text { The Pauper } \\
\text { (Mark Twain) } \\
\text { (English) }\end{array}$ & $\begin{array}{l}\text { The Prince } \\
\text { and The } \\
\text { Pauper } \\
\text { (English) }\end{array}$ & Za'ba & 1958 \\
\hline 2. & $\begin{array}{l}\text { Ratapan } \\
\text { Tanah Ayer }\end{array}$ & $\begin{array}{l}\text { Cry, The } \\
\text { Beloved } \\
\text { Country } \\
\text { (Alan Paton) } \\
\text { (English) }\end{array}$ & $\begin{array}{l}\text { Cry, The } \\
\text { Beloved } \\
\text { Country } \\
\text { (English) }\end{array}$ & Salleh Daud & 1965 \\
\hline 3. & $\begin{array}{l}\text { Pelayaran } \\
\text { Kapal Bounty }\end{array}$ & $\begin{array}{l}\text { The Tale of the } \\
\text { 'Bounty' } \\
\text { (H.G. Wyatt) } \\
\text { (English) }\end{array}$ & $\begin{array}{l}\text { The Tale of the } \\
\text { 'Bounty' } \\
\text { (English) }\end{array}$ & $\begin{array}{l}\text { A. Rahman } \\
\text { Yusof }\end{array}$ & 1976 \\
\hline 4. & Deru Ombak & $\begin{array}{l}\text { Shiosai } \\
\text { (Yukio } \\
\text { Mishima) } \\
\text { (Japanese) }\end{array}$ & $\begin{array}{l}\text { The Sound of } \\
\text { Waves } \\
\text { (Meredith } \\
\text { Weatherby) } \\
\text { (English) }\end{array}$ & $\begin{array}{l}\text { Shamsuddin } \\
\text { Jaafar }\end{array}$ & 1978 \\
\hline 5. & $\begin{array}{l}\text { Madu Dalam } \\
\text { Saringan }\end{array}$ & $\begin{array}{l}\text { Nectar in a } \\
\text { Sieve } \\
\text { (Kamala } \\
\text { Markandaya) } \\
\text { (English) }\end{array}$ & $\begin{array}{l}\text { Nectar in a } \\
\text { Sieve } \\
\text { (English) }\end{array}$ & $\begin{array}{l}\text { Mokhtar } \\
\text { Ahmad }\end{array}$ & 1979 \\
\hline 6. & $\begin{array}{l}\text { Orang } \\
\text { Terasing }\end{array}$ & $\begin{array}{l}\text { L'Étranger } \\
\text { (Albert Camus) } \\
\text { (French) }\end{array}$ & $\begin{array}{l}\text { The Outsider } \\
\text { (Stuart } \\
\text { Gilbert) } \\
\text { (English) }\end{array}$ & $\begin{array}{c}\text { Ainon } \\
\text { Muhammad }\end{array}$ & 1979 \\
\hline 7. & Tuah Semusim & $\begin{array}{l}\text { A Season of } \\
\text { Grace } \\
\text { (N.V.M. } \\
\text { Gonzalez) } \\
\text { (English) }\end{array}$ & $\begin{array}{l}\text { A Season of } \\
\text { Grace } \\
\text { (English) }\end{array}$ & $\begin{array}{l}\text { Zainuddin } \\
\text { Saad }\end{array}$ & 1981 \\
\hline
\end{tabular}


MALAY LITERATURE VOLUME 28 NUMBER 12015

\begin{tabular}{|c|c|c|c|c|c|}
\hline No. & $\begin{array}{c}\text { Title of } \\
\text { Translation } \\
\text { in Malay }\end{array}$ & $\begin{array}{c}\text { Title of } \\
\text { Original } \\
\text { Novel, Name } \\
\text { of Original } \\
\text { Author and } \\
\text { Original } \\
\text { Language of } \\
\text { Novel }\end{array}$ & $\begin{array}{c}\text { Title of } \\
\text { Source Text }\end{array}$ & $\begin{array}{l}\text { Name of } \\
\text { Translator }\end{array}$ & $\begin{array}{c}\text { Year of } \\
\text { Publication }\end{array}$ \\
\hline 8. & $\begin{array}{l}\text { Perjuangan } \\
\text { Sia-Sia }\end{array}$ & $\begin{array}{l}\text { In Dubious } \\
\text { Battle } \\
\text { (John Steinbeck) } \\
\text { (English) }\end{array}$ & $\begin{array}{c}\text { In Dubious } \\
\text { Battle } \\
\text { (English) }\end{array}$ & $\begin{array}{c}\text { Muhammad } \\
\text { Ridhwan }\end{array}$ & 1981 \\
\hline 9. & Lorong Midaq & $\begin{array}{l}\text { Zuqaq al-Midaq } \\
\text { (Naguib } \\
\text { Mahfouz) } \\
\text { (Arabic) }\end{array}$ & $\begin{array}{l}\text { Midaq Alley } \\
\text { (Trevor Le } \\
\text { Gassick) } \\
\text { (English) }\end{array}$ & $\begin{array}{l}\text { Abdullah } \\
\text { Hussain }\end{array}$ & 1983 \\
\hline 10. & $\begin{array}{l}\text {...Yang } \\
\text { Memilih } \\
\text { Jelatang }\end{array}$ & $\begin{array}{l}\text { Tade Kuu Mushi } \\
\text { (Junichiro } \\
\text { Tanizaki) } \\
\text { (Japanese) }\end{array}$ & $\begin{array}{l}\text { Some Prefer } \\
\text { Nettles } \\
\text { (Edward G. } \\
\text { Seidensticker) } \\
\text { (English) }\end{array}$ & $\begin{array}{c}\text { Mokhtar } \\
\text { Ahmad }\end{array}$ & 1985 \\
\hline 11. & Botchan & $\begin{array}{l}\text { Botchan } \\
\text { (Natsumi } \\
\text { Soseki) } \\
\text { (Japanese) }\end{array}$ & $\begin{array}{l}\text { Botchan } \\
\text { (Alan Turney) } \\
\text { (English) }\end{array}$ & $\begin{array}{c}\text { Mokhtar } \\
\text { Ahmad }\end{array}$ & 1986 \\
\hline 12. & $\begin{array}{l}\text { Totto Chan } \\
\text { Gadis Kecil di } \\
\text { Jendela }\end{array}$ & $\begin{array}{l}\text { Madogiwa no } \\
\text { Totto-chan } \\
\text { (Tetsuko } \\
\text { Kuroyanagi) } \\
\text { (Japanese) }\end{array}$ & $\begin{array}{l}\text { Totto Chan: } \\
\text { The Little Girl } \\
\text { at the Window } \\
\text { (Dorothy } \\
\text { Britton) } \\
\text { (English) }\end{array}$ & $\begin{array}{c}\text { Shamsuddin } \\
\text { Jaafar }\end{array}$ & 1986 \\
\hline 13. & $\begin{array}{l}\text { Hanya } \\
\text { Semalam }\end{array}$ & $\begin{array}{l}\text { Lailah Wahidah } \\
\text { (Kulit Suhail) } \\
\text { (Arabic) }\end{array}$ & $\begin{array}{c}\text { Lailah } \\
\text { Wahidah } \\
\text { (Arabic) }\end{array}$ & $\begin{array}{c}\text { Nahmar } \\
\text { Jamil }\end{array}$ & 1987 \\
\hline 14. & Kepulangan & $\begin{array}{l}\text { Kikyo } \\
\text { (Jiro Osaragi) } \\
\text { (Japanese) }\end{array}$ & $\begin{array}{c}\text { Homecoming } \\
\text { (Brewster } \\
\text { Horwitz) } \\
\text { (English) }\end{array}$ & $\begin{array}{l}\text { Amilah Ab. } \\
\text { Rahman \& } \\
\text { Junaidah } \\
\text { Salleh }\end{array}$ & 1987 \\
\hline 15. & $\begin{array}{l}\text { Korban } \\
\text { Fitnah }\end{array}$ & $\begin{array}{l}\text { Kham Phi } \\
\text { Phaksa } \\
\text { (Chart Kobjitti) } \\
\text { (Thai) }\end{array}$ & $\begin{array}{c}\text { The } \\
\text { Judgement } \\
\text { (Laurie } \\
\text { Maund) } \\
\text { (English) }\end{array}$ & $\begin{array}{l}\text { Mokhtar } \\
\text { Ahmad } \\
\text { \& Zainab } \\
\text { Ahmad }\end{array}$ & 1988 \\
\hline
\end{tabular}


HASLINA HAROON AND MELATI ABDUL MAJID

\begin{tabular}{|c|c|c|c|c|c|}
\hline No. & $\begin{array}{c}\text { Title of } \\
\text { Translation } \\
\text { in Malay }\end{array}$ & $\begin{array}{c}\text { Title of } \\
\text { Original } \\
\text { Novel, Name } \\
\text { of Original } \\
\text { Author and } \\
\text { Original } \\
\text { Language of } \\
\text { Novel }\end{array}$ & $\begin{array}{c}\text { Title of } \\
\text { Source Text }\end{array}$ & $\begin{array}{c}\text { Name of } \\
\text { Translator }\end{array}$ & $\begin{array}{c}\text { Year of } \\
\text { Publication }\end{array}$ \\
\hline 16. & $\begin{array}{l}\text { Kota Yang } \\
\text { Mencabar }\end{array}$ & $\begin{array}{l}\text { Mass } \\
\text { (F. Sionil José) } \\
\text { (English) }\end{array}$ & $\begin{array}{l}\text { Mass } \\
\text { (English) }\end{array}$ & $\begin{array}{l}\text { Hamdan } \\
\text { Yahya }\end{array}$ & 1988 \\
\hline 17. & Nyonya & $\begin{array}{l}\text { The Nyonya } \\
\text { (John M. Chin) } \\
\text { (English) }\end{array}$ & $\begin{array}{l}\text { The Nyonya } \\
\text { (English) }\end{array}$ & Hajijah Jais & 1988 \\
\hline 18. & Tuan Gatsby & $\begin{array}{l}\text { The Great } \\
\text { Gatsby } \\
\text { (F. Scott } \\
\text { Fitzgerald) } \\
\text { (English) }\end{array}$ & $\begin{array}{l}\text { The Great } \\
\text { Gatsby } \\
\text { (English) }\end{array}$ & $\begin{array}{c}\text { Ainon Abu } \\
\text { Bakar }\end{array}$ & 1988 \\
\hline 19. & $\begin{array}{l}\text { Yang Indah } \\
\text { Belum } \\
\text { Menjelma } \\
\text { Lagi }\end{array}$ & $\begin{array}{c}\text { The Beautyful } \\
\text { Ones Are Not } \\
\text { Yet Born } \\
\text { (Ayi Kwei } \\
\text { Armah) } \\
\text { (English) }\end{array}$ & $\begin{array}{l}\text { The Beautyful } \\
\text { Ones Are Not } \\
\text { Yet Born } \\
\text { (English) }\end{array}$ & $\begin{array}{l}\text { Zainab } \\
\text { Ahmad }\end{array}$ & 1988 \\
\hline 20. & $\begin{array}{l}\text { Bulan Retak } \\
\text { di Balik Awan }\end{array}$ & $\begin{array}{l}\text { The Moon and } \\
\text { Sixpence } \\
\text { (W. Somerset } \\
\text { Maugham) } \\
\text { (English) }\end{array}$ & $\begin{array}{l}\text { The Moon and } \\
\text { Sixpence } \\
\text { (English) }\end{array}$ & $\begin{array}{l}\text { Shamsuddin } \\
\text { Jaafar }\end{array}$ & 1989 \\
\hline 21. & Kim & $\begin{array}{c}\text { Kim } \\
\text { (Rudyard } \\
\text { Kipling) } \\
\text { (English) }\end{array}$ & $\begin{array}{l}\text { Kim } \\
\text { (English) }\end{array}$ & $\begin{array}{c}\text { Zainal } \\
\text { Abidin } \\
\text { Bakar }\end{array}$ & 1989 \\
\hline 22. & Musim & $\begin{array}{l}\text { Climats } \\
\text { (André Maurois) } \\
\text { (French) }\end{array}$ & $\begin{array}{l}\text { Climats } \\
\text { (French) }\end{array}$ & M.N. Djuli & 1989 \\
\hline 23. & $\begin{array}{l}\text { Untuk Siapa } \\
\text { Genta } \\
\text { Bergema }\end{array}$ & $\begin{array}{c}\text { For Whom The } \\
\text { Bell Tolls } \\
\text { (Ernest } \\
\text { Hemingway) } \\
\text { (English) }\end{array}$ & $\begin{array}{l}\text { For Whom } \\
\text { The Bell Tolls } \\
\text { (English) }\end{array}$ & $\begin{array}{l}\text { Zainab } \\
\text { Ahmad }\end{array}$ & 1989 \\
\hline
\end{tabular}




\begin{tabular}{|c|c|c|c|c|c|}
\hline No. & $\begin{array}{c}\text { Title of } \\
\text { Translation } \\
\text { in Malay }\end{array}$ & $\begin{array}{c}\text { Title of } \\
\text { Original } \\
\text { Novel, Name } \\
\text { of Original } \\
\text { Author and } \\
\text { Original } \\
\text { Language of } \\
\text { Novel }\end{array}$ & $\begin{array}{c}\text { Title of } \\
\text { Source Text }\end{array}$ & $\begin{array}{l}\text { Name of } \\
\text { Translator }\end{array}$ & $\begin{array}{c}\text { Year of } \\
\text { Publication }\end{array}$ \\
\hline 24. & Dewi Putih & $\begin{array}{l}\text { Lady White } \\
\text { (Ren Shaozeng) } \\
\text { (English) }\end{array}$ & $\begin{array}{l}\text { Lady White } \\
\text { (English) }\end{array}$ & $\begin{array}{c}\text { Rusnah } \\
\text { Talib }\end{array}$ & 1990 \\
\hline 25. & $\begin{array}{l}\text { Enggang Lalu } \\
\text { Ranting Patah }\end{array}$ & $\begin{array}{l}\text { To Kill A } \\
\text { Mockingbird } \\
\text { (Harper Lee) } \\
\text { (English) }\end{array}$ & $\begin{array}{l}\text { To Kill A } \\
\text { Mockingbird } \\
\text { (English) }\end{array}$ & $\begin{array}{l}\text { Khidmat } \\
\text { Terjemahan } \\
\text { Nusantara } \\
\text { Sdn. Bhd. }\end{array}$ & 1990 \\
\hline 26. & $\begin{array}{l}\text { Mereka yang } \\
\text { Terkurung }\end{array}$ & $\begin{array}{l}\text { Hlaung-chaine- } \\
\text { hte-ga-nhet-nge- } \\
\text { myar } \\
\text { (Ludu U Hla) }\end{array}$ & $\begin{array}{l}\text { The Caged } \\
\text { Ones } \\
\text { (Sein Tu) } \\
\text { (English) }\end{array}$ & $\begin{array}{c}\text { Omar } \\
\text { Ahmad }\end{array}$ & 1990 \\
\hline 27. & $\begin{array}{l}\text { Durjana di } \\
\text { Hati }\end{array}$ & $\begin{array}{l}\text { Heart of } \\
\text { Darkness } \\
\text { (Joseph Conrad) } \\
\text { (English) }\end{array}$ & $\begin{array}{l}\text { Heart of } \\
\text { Darkness } \\
\text { (English) }\end{array}$ & $\begin{array}{l}\text { Zulkifli } \\
\text { Ahmad }\end{array}$ & 1991 \\
\hline 28. & $\begin{array}{l}\text { Mendung } \\
\text { di Lembah } \\
\text { Assam }\end{array}$ & $\begin{array}{l}\text { Two Leaves and } \\
\text { a Bud } \\
\text { (Mulk Raj } \\
\text { Anand) } \\
\text { (English) }\end{array}$ & $\begin{array}{l}\text { Two Leaves } \\
\text { and a Bud } \\
\text { (English) }\end{array}$ & $\begin{array}{l}\text { Zainab } \\
\text { Ahmad }\end{array}$ & 1991 \\
\hline 29. & $\begin{array}{l}\text { Sumpah Tujuh } \\
\text { Keturunan }\end{array}$ & $\begin{array}{l}\text { Cien años de } \\
\text { soledad } \\
\text { (Gabriel García } \\
\text { Márquez) } \\
\text { (Spanish) }\end{array}$ & $\begin{array}{l}\text { One Hundred } \\
\text { Years of } \\
\text { Solitude } \\
\text { (Gregory } \\
\text { Rabassa) } \\
\text { (English) }\end{array}$ & $\begin{array}{c}\text { Mokhtar } \\
\text { Ahmad \& } \\
\text { Zulkifli } \\
\text { Ahmad }\end{array}$ & 1991 \\
\hline 30. & Tebing Tinggi & $\begin{array}{l}\text { Taling Soong } \\
\text { Sung Nak } \\
\text { (Nikhom } \\
\text { Raiyawa) } \\
\text { (Thai) }\end{array}$ & $\begin{array}{l}\text { Taling Soong } \\
\text { Sung Nak } \\
\text { (Thai) }\end{array}$ & $\begin{array}{l}\text { Suwanlerd } \\
\text { Pro Paul }\end{array}$ & 1991 \\
\hline 31. & Malam Kudus & $\begin{array}{l}\text { La Nuit Sacree } \\
\text { (Tahar Ben } \\
\text { Jelloun) } \\
\text { (French) }\end{array}$ & $\begin{array}{l}\text { La Nuit Sacree } \\
\text { (French) }\end{array}$ & $\begin{array}{c}\text { Puteri } \\
\text { Rashidah } \\
\text { Megat } \\
\text { Ramli }\end{array}$ & 1992 \\
\hline
\end{tabular}


HASLINA HAROON AND MELATI ABDUL MAJID

\begin{tabular}{|c|c|c|c|c|c|}
\hline No. & $\begin{array}{c}\text { Title of } \\
\text { Translation } \\
\text { in Malay }\end{array}$ & $\begin{array}{c}\text { Title of } \\
\text { Original } \\
\text { Novel, Name } \\
\text { of Original } \\
\text { Author and } \\
\text { Original } \\
\text { Language of } \\
\text { Novel }\end{array}$ & $\begin{array}{c}\text { Title of } \\
\text { Source Text }\end{array}$ & $\begin{array}{l}\text { Name of } \\
\text { Translator }\end{array}$ & $\begin{array}{c}\text { Year of } \\
\text { Publication }\end{array}$ \\
\hline 32. & $\begin{array}{l}\text { Berakhirnya } \\
\text { Balada Cinta }\end{array}$ & $\begin{array}{l}\text { Kallo Kaviyamo } \\
\text { (Mu. } \\
\text { Varatharasan) } \\
\text { (Tamil) }\end{array}$ & $\begin{array}{l}\text { Kallo } \\
\text { Kaviyamo } \\
\text { (Tamil) }\end{array}$ & $\begin{array}{c}\text { A. } \\
\text { Valarmathy }\end{array}$ & 1992 \\
\hline 33. & Cahaya Ogos & $\begin{array}{l}\text { Light In August } \\
\text { (William } \\
\text { Faulkner) } \\
\text { (English) }\end{array}$ & $\begin{array}{l}\text { Light In } \\
\text { August } \\
\text { (English) }\end{array}$ & $\begin{array}{l}\text { Shamsuddin } \\
\text { Jaafar }\end{array}$ & 1992 \\
\hline 34. & Halimunan & $\begin{array}{l}\text { Invisible Man } \\
\text { (Ralph Ellison) } \\
\text { (English) }\end{array}$ & $\begin{array}{l}\text { Invisible Man } \\
\text { (English) }\end{array}$ & $\begin{array}{l}\text { Zulkifli } \\
\text { Ahmad }\end{array}$ & 1992 \\
\hline 35. & $\begin{array}{l}\text { Datuk Bandar } \\
\text { Casterbridge }\end{array}$ & $\begin{array}{l}\text { The Mayor of } \\
\text { Casterbridge } \\
\text { (Thomas Hardy) } \\
\text { (English) }\end{array}$ & $\begin{array}{l}\text { The Mayor of } \\
\text { Casterbridge } \\
\text { (English) }\end{array}$ & $\begin{array}{l}\text { Ainon Abu } \\
\text { Bakar \& } \\
\text { Alauyah } \\
\text { Abd. } \\
\text { Rahman }\end{array}$ & 1992 \\
\hline 36. & $\begin{array}{l}\text { Duri-Duri } \\
\text { Liar }\end{array}$ & $\begin{array}{l}\text { Al-Subar } \\
\text { (Sahar Khalifeh) } \\
\text { Arabic }\end{array}$ & $\begin{array}{l}\text { Wild Thorns } \\
\text { (English) }\end{array}$ & Ajikik & 1992 \\
\hline 37. & $\begin{array}{l}\text { Isteri } \\
\text { Hanaoka } \\
\text { Seishu }\end{array}$ & $\begin{array}{l}\text { Hanaoka Seishu } \\
\text { No Tsuma } \\
\text { (Sawako } \\
\text { Ariyoshi) } \\
\text { (Japanese) }\end{array}$ & $\begin{array}{l}\text { Hanaoka } \\
\text { Seishu No } \\
\text { Tsuma } \\
\text { (Japanese) }\end{array}$ & $\begin{array}{l}\text { Thaiyibah } \\
\text { Sulaiman }\end{array}$ & 1992 \\
\hline 38. & $\begin{array}{l}\text { Sebuah } \\
\text { Kampung di } \\
\text { Pinggir Laut }\end{array}$ & $\begin{array}{l}\text { The Village By } \\
\text { The Sea } \\
\text { (Anita Desai) } \\
\text { (English) }\end{array}$ & $\begin{array}{l}\text { The Village By } \\
\text { The Sea } \\
\text { (English) }\end{array}$ & $\begin{array}{l}\text { Nor Azmah } \\
\text { Shehidan }\end{array}$ & 1992 \\
\hline 39. & Tiga Novela & $\begin{array}{l}\text { Three Novellas } \\
\text { (D.H. } \\
\text { Lawrence) } \\
\text { (English) }\end{array}$ & $\begin{array}{l}\text { Three } \\
\text { Novellas } \\
\text { (English) }\end{array}$ & $\begin{array}{c}\text { Khamariah } \\
\text { Ahamed }\end{array}$ & 1992 \\
\hline
\end{tabular}




\begin{tabular}{|c|c|c|c|c|c|}
\hline No. & $\begin{array}{c}\text { Title of } \\
\text { Translation } \\
\text { in Malay }\end{array}$ & $\begin{array}{c}\text { Title of } \\
\text { Original } \\
\text { Novel, Name } \\
\text { of Original } \\
\text { Author and } \\
\text { Original } \\
\text { Language of } \\
\text { Novel }\end{array}$ & $\begin{array}{c}\text { Title of } \\
\text { Source Text }\end{array}$ & $\begin{array}{c}\text { Name of } \\
\text { Translator }\end{array}$ & $\begin{array}{c}\text { Year of } \\
\text { Publication }\end{array}$ \\
\hline 40. & $\begin{array}{l}\text { Doktor Jekyll } \\
\text { dan } \\
\text { Encik Hyde }\end{array}$ & $\begin{array}{l}\text { Dr. Jekyll and } \\
\text { Mr. Hyde } \\
\text { (Robert Louis } \\
\text { Stevenson) } \\
\text { (English) }\end{array}$ & $\begin{array}{l}\text { Dr. Jekyll and } \\
\text { Mr. Hyde } \\
\text { (English) }\end{array}$ & $\begin{array}{l}\text { Normala } \\
\text { Othman }\end{array}$ & 1993 \\
\hline 41. & $\begin{array}{l}\text { Bermula dan } \\
\text { Berakhir }\end{array}$ & $\begin{array}{l}\text { Bidayah Wa- } \\
\text { Nihayah } \\
\text { (Naguib } \\
\text { Mahfouz) } \\
\text { (Arabic) }\end{array}$ & $\begin{array}{l}\text { The Beginning } \\
\text { and the End } \\
\text { (Ramses } \\
\text { Awad) } \\
\text { (English) }\end{array}$ & $\begin{array}{l}\text { Shamsuddin } \\
\text { Jaafar }\end{array}$ & 1993 \\
\hline 42. & Desa Salji & $\begin{array}{l}\text { Yukiguni } \\
\text { (Yasunari } \\
\text { Kawabata) } \\
\text { (Japanese) }\end{array}$ & $\begin{array}{l}\text { Snow Country } \\
\text { (Edward G. } \\
\text { Seidensticker) } \\
\text { (English) }\end{array}$ & $\begin{array}{c}\text { Ainon Abu } \\
\text { Bakar }\end{array}$ & 1993 \\
\hline 43. & Hujan Hitam & $\begin{array}{l}\text { Kuroi Ame } \\
\text { (Masuji Ibuse) } \\
\text { (Japanese) }\end{array}$ & $\begin{array}{l}\text { Black Rain } \\
\text { (John Bester) } \\
\text { (English) }\end{array}$ & $\begin{array}{c}\text { Fatimah } \\
\text { Zainal \& } \\
\text { Zulkifli } \\
\text { Ahmad } \\
\end{array}$ & 1993 \\
\hline 44. & $\begin{array}{l}\text { Merunut Akar } \\
\text { Meraih Bumi }\end{array}$ & $\begin{array}{l}\text { My Place } \\
\text { (Sally Morgan) } \\
\text { (English) }\end{array}$ & $\begin{array}{l}\text { My Place } \\
\text { (English) }\end{array}$ & Ajikik & 1993 \\
\hline 45. & $\begin{array}{l}\text { Moby Dick } \\
\text { atau Ikan } \\
\text { Paus Putih }\end{array}$ & $\begin{array}{l}\text { Moby Dick or } \\
\text { the White Whale } \\
\text { (Herman } \\
\text { Melville) } \\
\text { (English) }\end{array}$ & $\begin{array}{l}\text { Moby Dick } \\
\text { or the White } \\
\text { Whale } \\
\text { (English) }\end{array}$ & $\begin{array}{l}\text { Khidmat } \\
\text { Terjemahan } \\
\text { Nusantara }\end{array}$ & 1993 \\
\hline 46. & $\begin{array}{l}\text { Perhimpunan } \\
\text { Griot }\end{array}$ & $\begin{array}{l}\text { L'Assemblée } \\
\text { des Djinns } \\
\text { (Massa M. } \\
\text { Diabaté) } \\
\text { (French) }\end{array}$ & $\begin{array}{l}\text { L'Assemblée } \\
\text { des Djinns } \\
\text { (French) }\end{array}$ & $\begin{array}{c}\text { Ruhanas } \\
\text { Harun }\end{array}$ & 1993 \\
\hline 47. & Pertentangan & $\begin{array}{l}\text { The Interpreters } \\
\text { (Wole Soyinka) } \\
\text { (English) }\end{array}$ & $\begin{array}{l}\text { The } \\
\text { Interpreters } \\
\text { (English) }\end{array}$ & $\begin{array}{l}\text { Md. Salleh } \\
\text { Parman \& } \\
\text { Marzuki } \\
\text { Mohd. Johar }\end{array}$ & 1993 \\
\hline
\end{tabular}


HASLINA HAROON AND MELATI ABDUL MAJID

\begin{tabular}{|c|c|c|c|c|c|}
\hline No. & $\begin{array}{c}\text { Title of } \\
\text { Translation } \\
\text { in Malay }\end{array}$ & $\begin{array}{c}\text { Title of } \\
\text { Original } \\
\text { Novel, Name } \\
\text { of Original } \\
\text { Author and } \\
\text { Original } \\
\text { Language of } \\
\text { Novel }\end{array}$ & $\begin{array}{c}\text { Title of } \\
\text { Source Text }\end{array}$ & $\begin{array}{l}\text { Name of } \\
\text { Translator }\end{array}$ & $\begin{array}{c}\text { Year of } \\
\text { Publication }\end{array}$ \\
\hline 48. & $\begin{array}{l}\text { Selagi Angin } \\
\text { Bertiup }\end{array}$ & $\begin{array}{l}\text { Tant Que } \\
\text { Soufflera Le } \\
\text { Vent (Renee } \\
\text { Asgarally) } \\
\text { (French) }\end{array}$ & $\begin{array}{l}\text { Tant Que } \\
\text { Soufflera Le } \\
\text { Vent } \\
\text { (French) }\end{array}$ & $\begin{array}{c}\text { Mohd. } \\
\text { Ridzuan } \\
\text { Abd. Malek }\end{array}$ & 1993 \\
\hline 49. & Balasan Dosa & $\begin{array}{l}\text { Преступление } \\
\text { и наказание } \\
\text { (Fyodor } \\
\text { Dostoyevsky) } \\
\text { (Russian) }\end{array}$ & $\begin{array}{l}\text { Crime and } \\
\text { Punishment } \\
\text { (Constance } \\
\text { Garnett) } \\
\text { (English) }\end{array}$ & $\begin{array}{l}\text { Mokhtar } \\
\text { Ahmad }\end{array}$ & 1994 \\
\hline 50. & Ibu oh Ibu! & $\begin{array}{l}\text { Waga Haha } \\
\text { no ki (Yasushi } \\
\text { Inoue) } \\
\text { (Japanese) }\end{array}$ & $\begin{array}{l}\text { Chronicle of } \\
\text { My Mother } \\
\text { (Jean Oda } \\
\text { Moy) } \\
\text { (English) }\end{array}$ & $\begin{array}{c}\text { Fatimah } \\
\text { Zainal }\end{array}$ & 1994 \\
\hline 51. & $\begin{array}{l}\text { Jelatang } \\
\text { Malgudi }\end{array}$ & $\begin{array}{l}\text { The Man-Eater } \\
\text { of Malgudi } \\
\text { (R.K. Narayan) } \\
\text { (English) }\end{array}$ & $\begin{array}{l}\text { The Man- } \\
\text { Eater of } \\
\text { Malgudi } \\
\text { (English) }\end{array}$ & $\begin{array}{l}\text { Zaleha } \\
\text { Abidin }\end{array}$ & 1994 \\
\hline 52. & $\begin{array}{l}\text { Liang Shan- } \\
\text { Bo dan Zhu } \\
\text { Ying-Tai }\end{array}$ & $\begin{array}{l}\text { Liang Shan- } \\
\text { Bo and Zhu } \\
\text { Ying-Tai (Zhao } \\
\text { Qing-Ge) } \\
\text { (Chinese) }\end{array}$ & $\begin{array}{l}\text { Liang Shan- } \\
\text { Bo and Zhu } \\
\text { Ying-Tai } \\
\text { (Chinese) }\end{array}$ & $\begin{array}{c}\text { Tan Lai } \\
\text { Peng }\end{array}$ & 1994 \\
\hline 53. & $\begin{array}{l}\text { Penghujung } \\
\text { Senja }\end{array}$ & $\begin{array}{l}\text { The Remains of } \\
\text { the Day (Kazuo } \\
\text { Ishiguro) } \\
\text { (English) }\end{array}$ & $\begin{array}{l}\text { The Remains } \\
\text { of the } \\
\text { Day } \\
\text { (English) }\end{array}$ & $\begin{array}{c}\text { Hamdan } \\
\text { Yahya \& } \\
\text { Shamsuddin } \\
\text { Jaafar }\end{array}$ & 1994 \\
\hline 54. & $\begin{array}{l}\text { Tahun-tahun } \\
\text { yang Dinanti }\end{array}$ & $\begin{array}{l}\text { Onna Zaka } \\
\text { (Fumiko Enchi) } \\
\text { (Japanese) }\end{array}$ & $\begin{array}{l}\text { The Waiting } \\
\text { Years } \\
\text { (John Bester) } \\
\text { (English) }\end{array}$ & $\begin{array}{c}\text { Ramlah } \\
\text { Muhamad \& } \\
\text { Shamsuddin } \\
\text { Jaafar }\end{array}$ & 1994 \\
\hline 55. & Baotown & $\begin{array}{l}\text { Hsiao-pao } \\
\text { chuang } \\
\text { (Wang Anyi) } \\
\text { (Chinese) }\end{array}$ & $\begin{array}{l}\text { Baotown } \\
\text { (Martha } \\
\text { Avery) } \\
\text { (English) }\end{array}$ & $\begin{array}{l}\text { Ainon Abu } \\
\text { Bakar }\end{array}$ & 1995 \\
\hline
\end{tabular}




\begin{tabular}{|c|c|c|c|c|c|}
\hline No. & $\begin{array}{c}\text { Title of } \\
\text { Translation } \\
\text { in Malay }\end{array}$ & $\begin{array}{c}\text { Title of } \\
\text { Original } \\
\text { Novel, Name } \\
\text { of Original } \\
\text { Author and } \\
\text { Original } \\
\text { Language of } \\
\text { Novel }\end{array}$ & $\begin{array}{c}\text { Title of } \\
\text { Source Text }\end{array}$ & $\begin{array}{c}\text { Name of } \\
\text { Translator }\end{array}$ & $\begin{array}{c}\text { Year of } \\
\text { Publication }\end{array}$ \\
\hline 56. & Keluarga & $\begin{array}{l}\text { Jia } \\
\text { (Ba Jin) } \\
\text { (Chinese) }\end{array}$ & $\begin{array}{l}\text { Jia } \\
\text { (Chinese) }\end{array}$ & $\begin{array}{c}\text { Choo Puay } \\
\text { Hin }\end{array}$ & 1995 \\
\hline 57. & $\begin{array}{l}\text { Sebutir } \\
\text { Gandum }\end{array}$ & $\begin{array}{l}\text { A Grain of } \\
\text { Wheat } \\
\text { (Ngǔgǐ wa } \\
\text { Thiong'o) } \\
\text { (English) }\end{array}$ & $\begin{array}{l}\text { A Grain of } \\
\text { Wheat } \\
\text { (English) }\end{array}$ & $\begin{array}{c}\text { Khamariah } \\
\text { Ahamed \& } \\
\text { Melissa Wan } \\
\text { Yit Fong }\end{array}$ & 1995 \\
\hline 58. & $\begin{array}{l}\text { Pengembara- } \\
\text { an Tom } \\
\text { Sawyer }\end{array}$ & $\begin{array}{l}\text { The Adventures } \\
\text { of Tom Sawyer } \\
\text { (Mark Twain) } \\
\text { (English) }\end{array}$ & $\begin{array}{l}\text { The } \\
\text { Adventures of } \\
\text { Tom Sawyer } \\
\text { (English) }\end{array}$ & $\begin{array}{l}\text { Norwati } \\
\text { Md. Yusuf } \\
\text { \& Zaleha } \\
\text { Abidin }\end{array}$ & 1995 \\
\hline 59. & Voss & $\begin{array}{l}\text { Voss } \\
\text { (Patrick White) } \\
\text { (English) }\end{array}$ & $\begin{array}{l}\text { Voss } \\
\text { (English) }\end{array}$ & Ajikik & 1995 \\
\hline 60. & Warisan Kami & $\begin{array}{l}\text { I Nostri Antenati } \\
\text { (Italo Calvino) } \\
\text { (Italian) }\end{array}$ & $\begin{array}{l}\text { Our Ancestors } \\
\text { (Archibald } \\
\text { Colquhoun) } \\
\text { (English) }\end{array}$ & $\begin{array}{c}\text { Mokhtar } \\
\text { Ahmad \& } \\
\text { Zulkifli } \\
\text { Ahmad }\end{array}$ & 1995 \\
\hline 61. & $\begin{array}{l}\text { Gadis } \\
\text { Pingitan }\end{array}$ & $\begin{array}{l}\text { Little Women } \\
\text { (Louisa May } \\
\text { Alcott) } \\
\text { (English) }\end{array}$ & $\begin{array}{l}\text { Little Women } \\
\text { (English) }\end{array}$ & $\begin{array}{l}\text { Normala } \\
\text { Abdullah }\end{array}$ & 1995 \\
\hline 62. & Kalbu & $\begin{array}{l}\text { Kokoro } \\
\text { (Natsume } \\
\text { Soseki) } \\
\text { (Japanese) }\end{array}$ & $\begin{array}{l}\text { Kokoro } \\
\text { (Japanese) }\end{array}$ & $\begin{array}{l}\text { Thaiyibah } \\
\text { Sulaiman }\end{array}$ & 1996 \\
\hline 63. & $\begin{array}{l}\text { Potret Dorian } \\
\text { Gray }\end{array}$ & $\begin{array}{l}\text { The Picture of } \\
\text { Dorian Gray } \\
\text { (Oscar Wilde) } \\
\text { (English) }\end{array}$ & $\begin{array}{l}\text { The Picture of } \\
\text { Dorian Gray } \\
\text { (English) }\end{array}$ & $\begin{array}{c}\text { Siti Akmar } \\
\text { Abu Samah, } \\
\text { Sharifah } \\
\text { Nor Ali \& } \\
\text { Norlin Ali }\end{array}$ & 1996 \\
\hline
\end{tabular}


HASLINA HAROON AND MELATI ABDUL MAJID

\begin{tabular}{|c|c|c|c|c|c|}
\hline No. & $\begin{array}{c}\text { Title of } \\
\text { Translation } \\
\text { in Malay }\end{array}$ & $\begin{array}{c}\text { Title of } \\
\text { Original } \\
\text { Novel, Name } \\
\text { of Original } \\
\text { Author and } \\
\text { Original } \\
\text { Language of } \\
\text { Novel }\end{array}$ & $\begin{array}{c}\text { Title of } \\
\text { Source Text }\end{array}$ & $\begin{array}{l}\text { Name of } \\
\text { Translator }\end{array}$ & $\begin{array}{c}\text { Year of } \\
\text { Publication }\end{array}$ \\
\hline 64. & Si Fadet Kecil & $\begin{array}{l}\text { La Petite } \\
\text { Fadette } \\
\text { (George Sand) } \\
\text { (French) }\end{array}$ & $\begin{array}{l}\text { La Petite } \\
\text { Fadette } \\
\text { (French) }\end{array}$ & $\begin{array}{l}\text { Yusniza } \\
\text { Abdullah }\end{array}$ & 1996 \\
\hline 65. & $\begin{array}{l}\text { Bayangan } \\
\text { Pohon Delima }\end{array}$ & $\begin{array}{l}\text { Shadows of the } \\
\text { Pomegranate } \\
\text { Tree } \\
\text { (Tariq Ali) }\end{array}$ & $\begin{array}{l}\text { Shadows } \\
\text { of the } \\
\text { Pomegranate } \\
\text { Tree } \\
\text { (English) }\end{array}$ & $\begin{array}{l}\text { Mansor } \\
\text { Puteh }\end{array}$ & 1997 \\
\hline 66. & Meniti Senja & $\begin{array}{l}\text { Kokotsu no hito } \\
\text { (Sawako } \\
\text { Ariyoshi) } \\
\text { (Japanese) }\end{array}$ & $\begin{array}{l}\text { Kokotsu no } \\
\text { hito } \\
\text { (Japanese) }\end{array}$ & $\begin{array}{l}\text { Thaiyibah } \\
\text { Sulaiman }\end{array}$ & 1999 \\
\hline 67. & Wira Ladang & $\begin{array}{l}\text { The Catcher in } \\
\text { the Rye } \\
\text { (J.D. Salinger) } \\
\text { (English) }\end{array}$ & $\begin{array}{l}\text { The Catcher in } \\
\text { the Rye } \\
\text { (English) }\end{array}$ & $\begin{array}{l}\text { Zulkifli } \\
\text { Ahmad }\end{array}$ & 1999 \\
\hline 68. & $\begin{array}{l}\text { Anna } \\
\text { Karenina } \\
\text { (Volume 1) }\end{array}$ & $\begin{array}{l}\text { Anna Karenina } \\
\text { (Leo Tolstoy) } \\
\text { (Russian) }\end{array}$ & $\begin{array}{l}\text { Anna } \\
\text { Karenina } \\
\text { (English) }\end{array}$ & $\begin{array}{l}\text { Annuar } \\
\text { Ayob }\end{array}$ & 2000 \\
\hline 69. & $\begin{array}{l}\text { Anna } \\
\text { Karenina } \\
\text { (Volume 2) }\end{array}$ & $\begin{array}{l}\text { Anna Karenina } \\
\text { (Leo Tolstoy) } \\
\text { (Russian) }\end{array}$ & $\begin{array}{l}\text { Anna } \\
\text { Karenina } \\
\text { (English) }\end{array}$ & $\begin{array}{c}\text { Annuar } \\
\text { Ayob }\end{array}$ & 2000 \\
\hline 70. & Kota Niskala & $\begin{array}{l}\text { Das Schloß } \\
\text { (Franz Kafka) } \\
\text { (German) }\end{array}$ & $\begin{array}{l}\text { The Castle } \\
\text { (Edwin } \\
\text { Muir, Willa } \\
\text { Muir, Eithne } \\
\text { Wilkins and } \\
\text { Ernst Kaiser) } \\
\text { (English) }\end{array}$ & $\begin{array}{l}\text { Shamsuddin } \\
\text { Jaafar \& } \\
\text { Zainal } \\
\text { Abidin } \\
\text { Bakar }\end{array}$ & 2000 \\
\hline 71. & Haji Murat & $\begin{array}{l}\text { Hadji Murat } \\
\text { (Leo Tolstoy) } \\
\text { (Russian) }\end{array}$ & $\begin{array}{l}\text { Hadji Murat } \\
\text { (Russian) }\end{array}$ & $\begin{array}{c}\text { Victor } \\
\text { Pogadaev }\end{array}$ & 2001 \\
\hline
\end{tabular}


MALAY LITERATURE VOLUME 28 NUMBER 12015

\begin{tabular}{|l|l|l|l|c|c|}
\hline No. & $\begin{array}{c}\text { Title of } \\
\text { Translation } \\
\text { in Malay }\end{array}$ & $\begin{array}{c}\text { Title of } \\
\text { Original } \\
\text { Novel, Name } \\
\text { of Original } \\
\text { Author and } \\
\text { Original } \\
\text { Language of } \\
\text { Novel }\end{array}$ & $\begin{array}{c}\text { Title of } \\
\text { Source Text }\end{array}$ & $\begin{array}{c}\text { Name of } \\
\text { Translator }\end{array}$ & $\begin{array}{c}\text { Year of } \\
\text { Publication }\end{array}$ \\
\hline 72. & $\begin{array}{l}\text { Riwayat } \\
\text { Mayta }\end{array}$ & $\begin{array}{l}\text { Historia de } \\
\text { Mayta } \\
\text { (Mario Vargas } \\
\text { Llosa) } \\
\text { (Spanish) }\end{array}$ & $\begin{array}{l}\text { The Real Life } \\
\text { of Alejandro } \\
\text { Mayta } \\
\text { (Alfred Mac } \\
\text { Adam) } \\
\text { (English) }\end{array}$ & $\begin{array}{c}\text { Nazel } \\
\text { Hashim } \\
\text { Mohamad }\end{array}$ & 2001 \\
& & & & \\
\hline
\end{tabular}

